\title{
Psychological Well Being among Highly Religious and
}

\section{Low Religious Students}

\author{
Shaheen Falki $^{1 *}$, Dr. (Mrs.) Asiya Aijaz ${ }^{2}$
}

\section{ABSTRACT}

The aim of our study was to compare psychological well-being among highly religious and low religious students of Aligarh Muslim University, Aligarh. The hypothesis was that those who are more religious will display high level of psychological well-being to those who are less religious. The sample size for this study was 200 students - 137 highly religious and 63 low religious. The Highly Religious and Low Religious students were selected on the basis of their scores on Religiosity Scale and then their Psychological Well-Being was measured. The independent sample t-test scores indicated that there is a significant level of difference between the scores of highly religious and low religious students on their psychological well-being with the $\mathrm{t}$ score = 23.570 which was significant at .05 level of significance. Thus, the result of the study confirmed our hypothesis that highly religious students display high level of psychological well-being than low religious students.

Keywords: Well-Being, Psychological Well-Being, Religiosity

Today's hectic life had everyone thinking about their well-being and that of their loved ones. In earlier times, life was not only slow but there was also less competition among people for getting jobs and basic necessities of life. People use to gather in evenings in selected places to discuss their problem with other people of the village, society or community. They use to enjoy their achievements with everyone in the community. Trivial things use to bring smiles on their faces and made their days. They were happy and satisfied with whatever they were earning and however they were living. But now-a-days, people are not satisfied even if they are living in lap of luxuries. They are so busy with their lives that they don't even have time for themselves let alone their loved ones. Instead of getting happy with their achievements they try to achieve more and more without actually enjoying their achievements. Thus, well-being on whole is decreasing day-by-day. Therefore researchers mostly revolve their researches around well-being and its dimensions because it is the most important topic for present generation.

\footnotetext{
${ }^{1}$ Research Scholar, Dept. of Psychology, AMU, Aligarh, Uttar Pradesh, India

${ }^{2}$ Professor, Dept. of Psychology, AMU, Aligarh, Uttar Pradesh, India

*Responding Author

(c) 2016 I S Falki, A Aijaz; licensee IJIP. This is an Open Access Research distributed under the terms of the Creative Commons Attribution License (http://creativecommons.org/licenses/by/2.0), which permits unrestricted use, distribution, and reproduction in any Medium, provided the original work is properly cited.
} 
According to common man, well-being is a state of being comfortable, healthy and happy with ourselves and our life as whole. But what actually is well-being? Friedli (2009) defines wellbeing as feeling good and functioning well. This includes having a fair share of material resources, influence and control, a sense of meaning, belonging and connection with people and place and the capability to manage problems and change. Well-being comprises people's evaluations, both affective and cognitive of their lives (Diener \& Suh, 1997). Even the philosophical literature refers to the 'simple notion' of well-being (i.e. 'a life going well') in a variety of ways, including a person's good, benefit, advantage, interest, prudential value, welfare, happiness, flourishing, eudemonia, utility, quality of life, and thriving (Angner, 2008). According to well-being index at AUT University the term well-being indicates two things how people feel and how they function in their lives. According to them there are more aspects that give people a sense of how their lives are going and not just happiness and being well. Their 'how people feel' refers to feeling such as happiness, joy, curiosity, sadness and anxiety, while their 'how people function' relates to competency, engagement, our personal relationships and sense of purpose in life. According to them our well-being is influenced by the actions we take and the way we think i.e. our attitude, sense of purpose and personal values. There are five essential elements or in other words components of well-being and according to Tom Rath and Jim Harter (2010) in their book - 'Well-Being: The Five Essential Elements' and they are:

1. Career Well-Being - This is the first element which is about how you occupy your time or simply liking what you do every day.

2. Social Well-Being - This element is about having strong relationships and love in your life.

3. Financial Well-Being - This element is about effectively managing your economic life.

4. Physical Well-Being - The fourth element is about having good health and enough energy to get things done on a daily basis.

5. Community Well-Being - The fifth element is about the sense of engagement you have with the area here you live.

Psychological well-being refers to how people evaluate their lives or how they perceive their lives. It is more than simple joy or happiness and it is also more than absence of depression and anxiety. We can say it is the feeling that we are living our life in enjoyable and rewarding way. According to Diener (1997), these evaluations may be in the form of cognitions or in the form of affect. The cognitive part is an information based appraisal of one's life that is when a person gives conscious evaluative judgments about one's satisfaction with life as a whole. The affective part is a hedonic evaluation guided by emotions and feelings such as frequency with which people experience pleasant/unpleasant moods in reaction to their lives. Shek (1992) defines psychological well-being as that "state of mentally healthy person who possess a number of positive mental health qualities such as active adjustment to the environment, and unity of personality". While according to Carr (2002), "Psychological Well-Being could be defined as the 
achievement of one's full psychological potential.” According to Carol Ryff, wellbeing could be broken down into different components, like:

- Self-acceptance - It is a positive attitude toward yourself; acknowledging and accepting multiple aspects of self, feeling positive about your past life, etc. It is how we accept ourselves as we are and how happy and satisfied we are with ourselves.

- Personal growth - It is a feeling of continued development and potential, and being open to new experiences. Do we think that our life is moving forward? Are we learning anything new every day? Are we having continuous growth in our personal life every day or our life has stopped?

- Purpose in life - It is having goals and a sense of direction in life. Feeling that both present and past experiences are meaningful, holding beliefs that give purpose to life. It is having aim in life. It is having a thing to look forward to everyday.

- Environmental mastery - It is feeling competent and able to manage a complex environment, choosing or creating personally suitable contexts. It is being able to say; "I am good at managing the responsibilities of daily life.". How did I manage the practicalities of getting through today? What did I do well in there?"

- Autonomy - It is being self-determining, independent and regulating our behaviour internally. It is resisting social pressures to think and act in certain ways and evaluating ourselves by personal standards.

- Positive relations with others - It is having warm, satisfying, trusting relationships. It is being concerned about others' welfare, being capable of strong empathy, affection and intimacy. It is understanding give-and-take of human relationships.

Most people can define religiosity as the beliefs, customs or practices that are related to particular religions like Islam, Christianity, Hinduism, Sikhism etc. According to Wikipedia Religiosity, in its broadest sense, is a comprehensive sociological term used to refer to the numerous aspects of religious activity, dedication, and belief (religious doctrine). Another term that would work equally well, though less often used, is religiousness. And in its narrowest sense, religiosity deals more with how religious a person is, and less with how a person is religious (in practicing certain rituals, retelling certain stories, etc).

So what actually does being religious do to us? How does religious help us in our day-to-day life? How does religion guide us in our crises and sorrows? It is seen that religion not only helps us in our time of need but also guides us throughout our lives. Pargament (2000) identifies five key functions of religion in conformity with the ways of approaching religion throughout time and through all religions. They are:

1. Significance / Sense - According to Clifford Geertz (1966), religion plays a key role in our journey for meaning or significance of life. When we are met difficult situations in our life, it is religion which offers us an understanding and interpretations of our troubles. 


\section{Psychological Well Being among Highly Religious and Low Religious Students}

2. Control - Erich Fromm (1950) stresses the role of religion in the search for control. When we face events that are beyond our means, it is religion that offers us methods of restoring our feelings of power and control over the situation.

3. Comfort / Spirituality - Freudian theorists pointed out that religion helps us in reducing our anxiety in a world where anything can happen at any time. Spirituality and the desire to connect with a divine and powerful force beyond ourselves are the basic functions of religion.

4. Intimacy / Spirituality - According to Durkheim (1915) religion helps in building social unity. Religion is way for promoting social harmony and social identity. Intimacy with the society is encouraged through spiritual methods such as offering spiritual support to other people and by getting spiritual support forms the clergymen, priests, maulanas, pundits etc.

5. Transformation / Changes in life - While it is seen that religion plays a conservative role by helping people maintain sense, control, comfort, intimacy and closeness to God. But religion also plays an important part in the bringing major changes through finding new meanings in life.

It is seen that religion also helps in promoting meaning and purpose of life while reducing anxiety among religious individuals. (Petersen \& Roy 1985). An increased interest in the effects of religion on mental health and psychological wellbeing is apparent in psychological literature. A number of well conducted clinical and epidemiological studies have shown that the religiosity committed had much less psychological distress than the uncommitted (William, Larson, Buckler, Heckman \& Pyle, 1991). There have been extensive reviews on the various mechanisms through which religion is beneficial, as well as detrimental, on specific aspects of psychological health (Pargament 1997; Pargament et al. 1998; Schumaker 1992). It is seen that religion can help in coping with negative life events or chronic illness (Pargament 1997). According to Shobhna Joshi, Shilpa Kumari and Madhu Jain (2008) there is an on-going interest in the relationship between psychological wellbeing and religiosity. Based on the studies cited in their paper they confirm the positive link between religious beliefs and psychological well-being. There are substantial evidences that religion and spirituality are strongly associated with mental health and psychological well-being (e.g., Chamberlain and Zika 1992; Hill and Pargament 2003). It also protects individual from suicide and substance misuse (Moreira-Almeida et al. 2006). More recent research that has more finely pictured the constructs of religion and spirituality points to a largely positive association with psychological well-being (Hill and Pargament 2003). Several studies have demonstrated a positive relationship between religiosity and psychological well-being. According to the review of more than 100 studies it is seen that people who are frequently involved in religious activities and highly value their religious faiths are at reduced risk for depression.

Yet, individuals who follow their religion seriously can also exhibit poorer mental health (Greenway, Meagan, Turnbull and Milne 2007). This is because it can be 'judgemental, 
alienating and exclusive' (Williams and Sternthal 2007) and lead to stress or guilt through nonconformity (Trenholm et al. 1998). Mentally ill patients are at higher risk of mortality when they experience religious doubts (Pargament et al. 2001).

Mostly the result of studies on religion and well-being have indicated that there is a positive relationship between the two, i.e. if the person is religious than his/her psychological well-being is high. This study is to understand that whether the psychological well-being of the youth in Aligarh Muslim University are also positively related to their level of religiosity as it is seen in most of the researches mentioned above.

\section{OBJECTIVE}

- To examine whether there is any difference in Psychological Well-Being of Highly Religious and Low Religious students.

\section{Hypothesis}

- The hypothesis is that those who are more religious will display high levels of Psychological Well-Being than those who are less religious.

\section{METHOD}

\section{Participants}

The sample of this study was students of Aligarh Muslim University - Graduates and Undergraduates students. The sample included 200 subjects out of which 137 were highly religious and 63 were low religious. Their ages ranged from 19 to 24 years. The majority of respondents were undergraduates (73\%) while rest were graduates (27\%). The data was collected by the means for both Religiosity and Psychological Well-Being during the month of August and September, 2014.

\section{Tools}

1. Psychological Well-Being Questionnaire developed by Bhogly \& Jai Prakesh (1995) was used in this study to measure Psychological Well-Being of students. This scale consists of 28 items with alternative response categories - Yes and No, designed to measure 13 dimensions of Well-Being including meaninglessness, somatic symptoms, selflessness, positive effects, daily activity, life satisfaction, suicidal ideas, personal control, social support, tension, wellness, general efficiency and satisfaction. The reliability was found to be .717. In terms of validity it correlates well, both with Subjective Well-Being Scale $(r=.622)$ and with General Well-Being Scale $(r=.484)$.

2. The Religiosity Scale which was developed by Deka \& Broota in 1985 was used to measure the level of religiosity of students. This scale consists of 44 items out of which 25 were positive and 19 were negative. The reliability coefficient for the religiosity scale is .96 for an adult sample of subject. 


\section{Procedure}

The present study is based on students of Aligarh Muslim University, Aligarh, Uttar Pradesh. The subjects in this study were either graduate or undergraduate students. All the subjects were given both Scales, i.e. Religiosity Scale and Psychological Well-Being Scale to complete. The set of instructions were read out to the subjects for both scales and they were asked to inform if they couldn't understand any statement in any of the scale. In Religiosity Scale the response category was divided into 5 - from strongly agree to strongly disagree, while in Psychological Well-Being Scale the response were any one of two categories - yes or no. Subjects were also asked to fill the scale truthfully and to the best of their knowledge and finally they were reminded that there are no right and wrong answers. After completing the scale all the subjects were thanked and the completed scales were collected from them. Then the scoring of the scales was started. On the basis of their scores on Religiosity Scale, 2 groups were formed - Highly Religious students and Low Religious students. Those who students who scored more than 140 were placed in Highly Religious Group and those students who scored less than 140 were placed in Low Religious Group. And then their scores on Psychological Well-Being were calculated. Ten items were negatively scored, rest were positively scored. Score assigned to a response is either 1 or 0 . In positively keyed items each 'Yes' response was scored as 1 , whereas in negatively keyed item a score of 1 was assigned to 'No'. The total score on this scale gave the estimation of the Psychological Well-Being, that is, the higher the score the greater the psychological well-being. Those who scored more than 14 were having high Psychological WellBeing and those who scored less than 14 were having low Psychological Well-Being. The data obtained was tabulated group wise.

\section{Data Analysis}

The mean score for Highly Religious Group was calculated by adding all the scores of Psychological Well-Being (PWB) of highly religious group and then dividing them by total

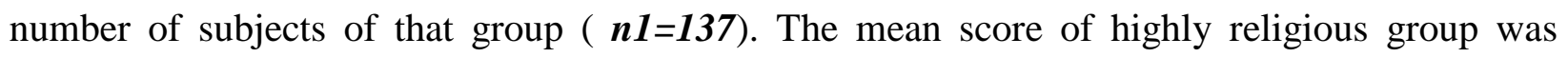
20.912 while the SD was 4.068. Similarly the mean and SD of low religious group was also calculated. Their mean was 7.206 while their SD was 3.209. (n2=63). T-test for independent sample was used for the present study to know whether there was difference in psychological well-being of highly religious and low religious people. The value obtained by t-test was $\mathbf{2 3 . 5 7 0 .}$

\section{RESULT AND DISCUSSION}

\begin{tabular}{|l|l|l|l|l|l|l|l|}
\hline Dimension & Groups & N & df & Mean & SD & t-value & p-value \\
\hline Psychological & Highly Religious & 137 & \multirow{2}{*}{198} & 20.912 & 4.068 & \multirow{2}{*}{23.570} & $>0.05$ \\
\cline { 2 - 3 } Well-Being & Low Religious & 63 & & 7.206 & 3.209 & & \\
\hline
\end{tabular}

Table 1. Indicates Mean, SD \& t-value of highly religious and low religious students on Psychological Well-Being Dimension 


\section{Psychological Well Being among Highly Religious and Low Religious Students}

The result reported in the Table 1 reveals that there is a significant difference between psychological well-being of Highly Religious and Low Religious students on all the 13 dimensions of psychological well-being at 0.05 level of significance. The calculated $t$ value (123.570) at 0.05 level of significance is greater than the critical t value (14.853) which means that null hypothesis is rejected i.e. there is a significance difference between the means of two set of scores.

On the basis of mean and SD of the scores, it appeared that Highly Religious students scored higher than Low Religious students on overall psychological well-being and its dimensions. The psychological well-being of highly religious students was found relatively better as compared to low religious students.

The purpose of this paper is to contribute to a theoretical understanding of role of religion in promoting psychological well-being. The findings of our study clearly indicate that religiosity plays an important role in psychological well-being of an individual. Though the sample of our study was quite small, previous researches in this area support the result so this can be generalised. It is seen that in religious group, religion is very important aspect of their life or we can say religion plays central importance to these individuals; they view religious interpretations as important and relevant in understanding their own life aspects. For example, if they are going through bad phase of life they cope up with it by assuming that it is God's way of testing their faith in him, this perception reduces their anxiety and stress. Sometimes they think that, God knows what's best for them and will do best for them and this reduced their anxiety. It is also seen that religion reduces anxiety by offering an explanatory model of personal and world events, it offers a sense of hope, meaning and purpose, resulting in psychological well-being in an individual. Religion also offers a sense of identity, satisfies the need for belonging, and unites people around shared understandings thus helps in promoting psychological well-being in an individual. Thus faith in God and being religious help them in coping up with many difficulties of their lives, and making them satisfied and happy in their lives and hence helps in promoting their psychological well-being. Even religious groups are good way for promoting psychological well-being in religious students as when they are participating in any religious programmes they tend to discuss their problems and the religious leaders try to solve their by quoting some of the verses of religious books like - "God is there and he has send thousands of angels to help us in dealing with our problems." and these reduces the anxiety and depression in an individual. Some of the verses from various religious texts which help in increasing psychological well-being are as follows: 
Verses from Holy Quran with their meaning:

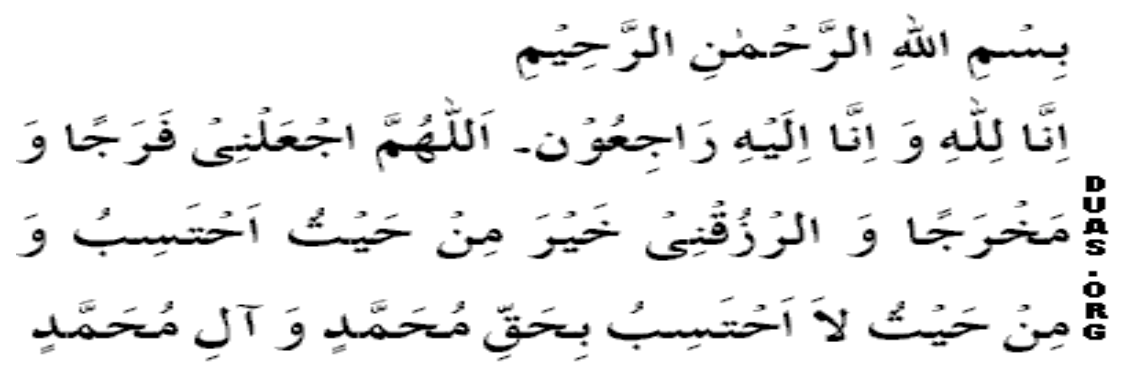

"Inna lillahi wa inna ilaihi raje oon .Allahummajalni farajawn wa makhrajan war zuqni khaira min haiso ahtasibo wa min haiso la ahtasib, be haqqe Mohammadin wa ale mohammad"

We are from Allah \& will return to HIM... Let my affairs be free from care \& make them profitable \& give me means of livelihood from my share $\&$ from where I have no expectation... by Muhammad \& his Family

\section{Verses from Bible with their meaning:}

Philippians 4:6-7 - "Do not be anxious about anything, but in everything, by prayer and petition, with thanksgiving, present your requests to God. And the peace of God, which transcends all understanding, will guard your hearts and your minds in Christ Jesus”.

John 14:27 - "Peace I leave with you; my peace I give to you. I do not give to you as the world gives. Do not let your hearts be troubled and do not be afraid.”

Isaiah 40: 30,31 - "Even youths grow tired and weary, and young men stumble and fall; but those who hope in the Lord will renew their strength. They will soar on wings like eagles; they will run and not grow weary, they will walk and not be faint."

Romans 16:20 - "The God of peace will soon crush Satan under your feet. The grace of our Lord Jesus be with you."

\section{Verses from Bhagwat Gita with their meaning:}

In Bhagawat Gita Chapter 2 verse 11, Lord Krishna starts his teaching by saying,

\section{श्रीभगवानुवाच |}

अशोच्यानन्वशोचस्त्वं प्रज्ञावादांश्च भाषसे |

गतासूनगतासूंश्च नानुशोचन्ति पण्डिता: || 11\|

"Sri bhagavan uvacha, asocyan anvasochas tvam, pranjna-vadams cha bhasase, gatasun agatasums cha, nanusochanti panditah” 
"Sri Bhagavan said: arjuna, You speak the learned words but you are mourning for what is not worthy of grief \& not be mourned. Those who are wise mourn neither for the living nor for the dead.”

\section{Verses from Sri Guru Granth Sahib and their meaning:}

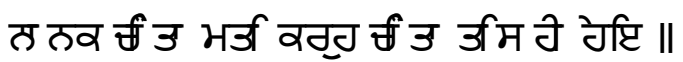

Nanak chintaa mati karahu chintaa tis hee hei

O Nanak, don't worry; the Lord will take care of you (sggs 955).

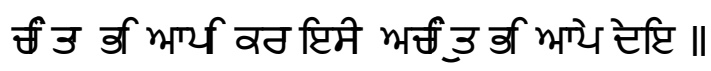

Chintaa bhi aapi karaaisee achint bhi aape dei

He Himself makes the mortals worry, and He Himself takes the worry away (sggs 1376).

\section{REFERENCES}

Angner, E. (2008). The philosophical foundations of subjective measures of well-being. Capabilities and Happiness, 286-29.

Camfield, L., Streuli, N., \& Woodhead, M. (2010). Children's Well-being in Developing Countries: A Conceptual and Methodological Review. European Journal of Development Research, 22(3), 398-416.

Carr, A.(2002). Positive Psychology: The science of happiness and human strength. New York: Routledge.

Chamberlain, K., \& Zika, S. (1992). Religiosity, meaning in life, and psychological wellbeing. In J. F. Schumaker (Ed.), Religion and mental health (pp. 138-148). New York: Oxford University Press.

Diener, E., \& Fujita, F. (1997). Social comparisions and subjective well-being. In B. Buunk \& R. Gibbons (Eds.), Health, coping, and social comparison. (pp. 329-357). Mahwah, NJ: Eribaum.

Diener, E., \& Suh, , E.M. (1997). Measurung quality of life: Economic, social and subjective indicators. Social Indicators Research, 40, 189-216.

Durkheim, Emile, (1915), "The elementary forms of the religious life, a study in religious sociology”. Publisher London : G. Allen \& Unwin; New York, Macmillan, Call number srlf_ucla:LAGE-1126912

Friedli, L. (2009) 'Mental health, resilience and inequalities', World Health Organization.

Fromm, Erich (1950). Psychoanalysis and Religion. New Haven, CT, United States: Yale University Press. ISBN 0-300-00089-8. Retrieved 10 February 2010.

Geertz, Clifford. (1966). Religion as a Cultural System. Anthropological Approaches to the Study of Religion. Ed. Michael Banton. pp. 1-46. ASA Monographs, 3. London: Tavistock Publications.

Greenway, A. P., Meagan, P., Turnbull, S., \& Milne, L. C. (2007). Religious coping strategies and spiritual transcendence. Mental Health, Religion and Culture, 10, 325-333. 


\section{Psychological Well Being among Highly Religious and Low Religious Students}

Hill, P. C., \& Pargament, K. I. (2003). Advances in the conceptualization and measurement of religion and spirituality: Implications for physical and mental health research. American Psychologist, 58, 64-74.

Larry R. Petersen \& Anita Roy (1985). Religiosity, anxiety, and meaning and purpose: Religion's Consequences for Psychological Well-Being. Review of Religious Research, Vol. 27, No.1 (Sept, 1985), pp. 49-62.

Moreira-Almeida, A., Neto, F. L., \& Koenig, H. G. (2006). Religiousness and mental health: A review.

Pargament, K. I. (1997). The psychology of religion and coping. New York: Guilford Press.

Pargament, K. I., Koenig, H. G., Tarakeshwar, N., \& Hahn, J. (2001). Religious struggle as a predictor of mortality among medically ill elderly patients: A 2-year longitudinal study. Archives of Internal Medicine, 161, 1881-1885.

Pargament, K. I., Smith, B. W., Koenig, H. G., \& Perez, L. (1998). Patterns of positive and negative religious coping with major life stressors. Journal for the Scientific Study of Religion, 37, 710-724.

Pargament, K.I. and Koenig, H.G. and Perez, L.M. (2000). ”The many methods of religious coping: development and initial validation of the RCOPE", Journal of Clinical Psychology, 56, 519-543.

Rath, T. and Jim Harter (2010). Wellbeing: The Five Essential Elements. Gallup Press

Religiosity (n.d.). In Wikipedia. Retrieved February 25, 2016 from https://en.wikipedia.org/wiki/Religiosity

Schumaker, J. F. (1992). Religion and mental health. New York: Oxford University Press

Shek, D. (1992). Meaning in life and psychological well-being: an empirical study using the Chinese version of the purpose in life questionnaire. Journal of Genetic Psychology, 153, 185-190.

Shobhna Joshi, Shilpa Kumari and Madhu Jain (2008). Religious Belief and Its Relation to Psychological Well-being. Journal of the Indian Academy of Applied Psychology, July 2008, Vol. 34, No.2, 345-354.

Trenholm, P., Trent, J., \& Compton, W. C. (1998). Negative religious conflict as a predictor of panic disorder. Journal of Clinical Psychology, 54, 59-65.

Verma, S.K. \& Verma, A. (1989). PGI General Wellbeing Measure. Lucknow: Ankur Psychological Agency

Verses of Bhagavat Gita, its translation and meaning. Reserved February 25, 2016 fromhttp://www.holy-bhagavad-gita.org/chapter/2/verse/11

Verses of Holy Bible, its translation and meaning. Reserved February 25, 2016 from http://lynndove.com/2012/05/23/25-encouraging-bible-verses-for-stress/

Verses of Holy Quran, its translation and meaning. Reserved February 25, 2016 from http://www.duas.org/misc.htm

Verses of Sri Guru Granth Sahib, its translation and meaning. Reserved February 25, 2016 from http://www.gurbani.org/articles/webart159.htm 
Willams, R. W., Larson, D. B., Bukler, R. E., Heckman. R. C., \& Pyle, C. M. (1991). Religion and psychological distress in a community sample. Social Science, Medicine, 32, 12571262.

Williams, D. R., \& Sternthal, M. J. (2007). Spirituality, religion and health: evidence and research directions. Medical Journal of Australia, 186, S47-S50. 